\title{
Oligoclonal "fingerprint" of CSF IgG in multiple sclerosis patients is not modified following intrathecal administration of natural beta-interferon
}

\author{
CHRISTIAN CONFAVREUX, ${ }^{*}$ COLETTE CHAPUIS-CELLIER, $\dagger$ \\ PHILIPPE ARNAUD $\ddagger$ OLIVIER ROBERT, ${ }^{*}$ GILBERT AIMARD, ${ }^{*}$ MICHEL DEVIC* \\ From the Service de Neurologie Hôpital Neurologique, ${ }^{*}$ Laboratoire de Biochimie B Hôpital Edouard Herriot, $\dagger$ \\ Lyon, France, Department of Basic and Clinical Immunology and Microbiology, Medical University of South \\ Carolina, Charleston, SC, USA.
}

SUMmaRY The IgG pattern in CSF was studied in 11 patients with multiple sclerosis who exhibited an oligoclonal banding upon thin-layer polyacrylamide gel isoelectric focusing followed by silver stain of unconcentrated CSF. Each patient received beta-interferon intrathecally during a 2 month period. No modification was observed over a 6 month period. In addition, the oligoclonal pattern was remarkably unique for each individual representing a typical "fingerprint" which allowed the identification of any single CSF.

The presence of an oligoclonal pattern of Immunoglobulin G (IgG) in the cerebrospinal fluid (CSF) of patients with multiple sclerosis has been recognized since the $1960 \mathrm{~s}$, using electrophoretic techniques. ${ }^{1-3}$ It has been shown to be stable throughout the course of the disease ${ }^{45}$ with some exceptions. ${ }^{6}$ The introduction of isoelectric focusing (IEF), with its high resolving capacity for the study of oligoclonal IgG bands, ${ }^{7}$ has increased the diagnostic yield of CSF analysis in multiple sclerosis. ${ }^{8}$ With this technique, each patient seems to have a unique band pattern of IgG which remains stable throughout the course of the disease..$^{9-11}$ In this paper, we report our experience of long-term follow up of CSF IgG band pattern by IEF of unconcentrated CSF in 11 patients with multiple sclerosis.

\section{Material and methods}

Eleven subjects with definite multiple sclerosis according to

\footnotetext{
Address for reprint requests: Dr C Confavreux, Hôpital Neurologique, 59 boulevard Pinel, 69003, Lyon, France.
}

Received 29 October 1985 and in revised form 15 January 1986. Accepted 17 January 1986
MacAlpine's criteria ${ }^{12}$ were studied. The course of the disease was progressive as previously defined. ${ }^{13}$ All eleven patients exhibited an oligoclonal CSF IgG pattern by thinlayer IEF. ${ }^{14}$ Oligoclonal pattern was defined as bands present in CSF but not in serum, or more intense in CSF than in serum when equal amounts of CSF and serum IgG were used for IEF.

The patients received natural beta-interferon (IFN) (UPSA Laboratories) intrathecally. Six cases received $100.000 \mathrm{U}$ and the five other patients $640.000 \mathrm{U}$ of IFN at weekly intervals for eight weeks. Paired serum and CSF were obtained prior to each injection and one and four months following the last injection. This survey covered a total period of six months. No other immunomodulating agent was given during the study.

Following standard cytological and biochemical assays, paired serum and CSF were stored at $-70^{\circ} \mathrm{C}$. IEF was performed on thin-layer polyacrylamide gels (Ampholine $\mathrm{pH}$ range 3.5-10) and followed by silver stain using unconcentrated CSF and diluted serum as previously described. ${ }^{14}$ The total amount of IgG applied to the cathodic side of the gel was $2 \mu \mathrm{g}$ in each case.

\section{Results}

The number, mobility and intensity of the oligoclonal bands of CSF IgG were clearly different from patient to patient (fig a) and showed no qualitative change during the survey within each individual (fig b). From 

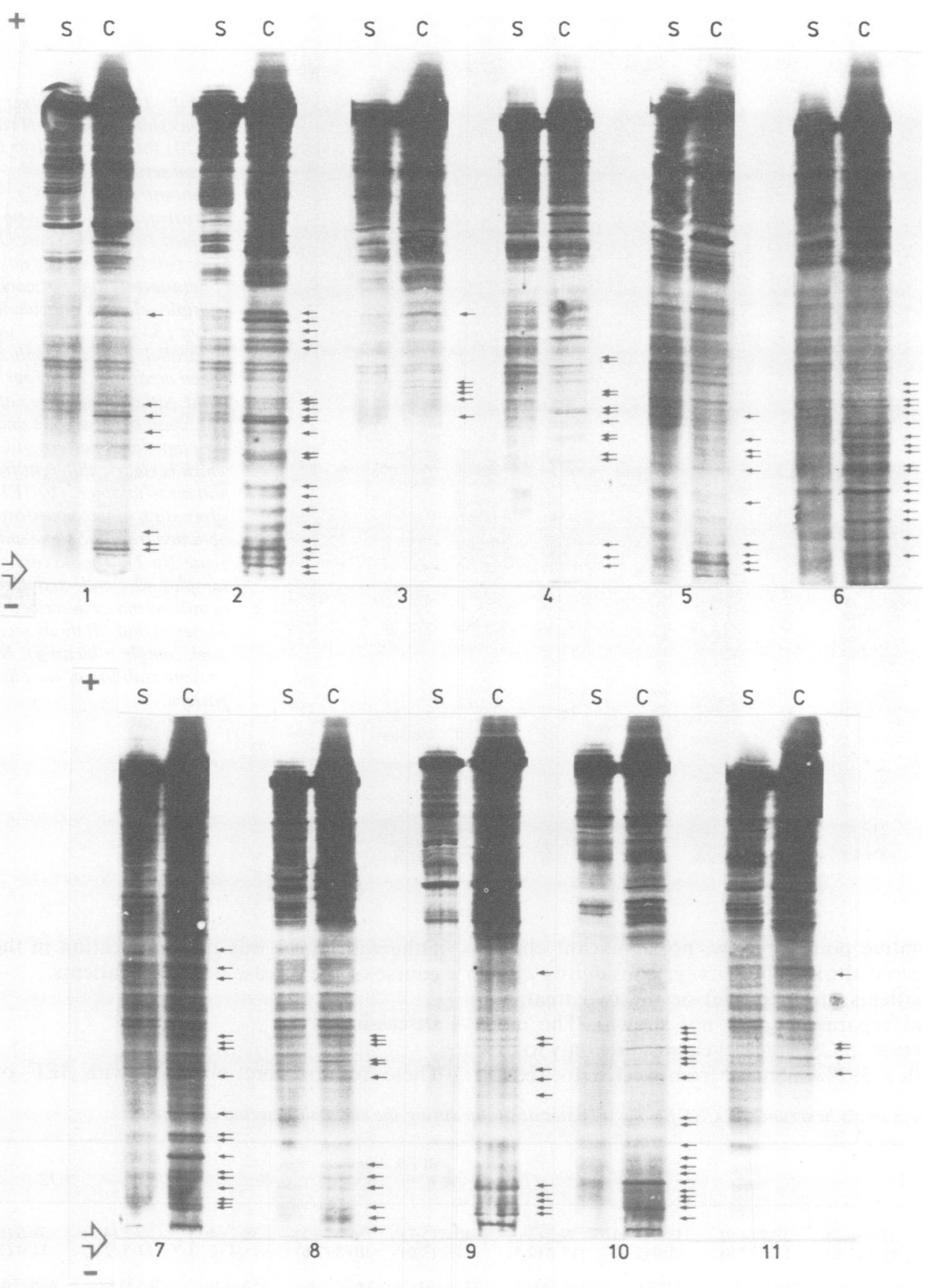

(a) 


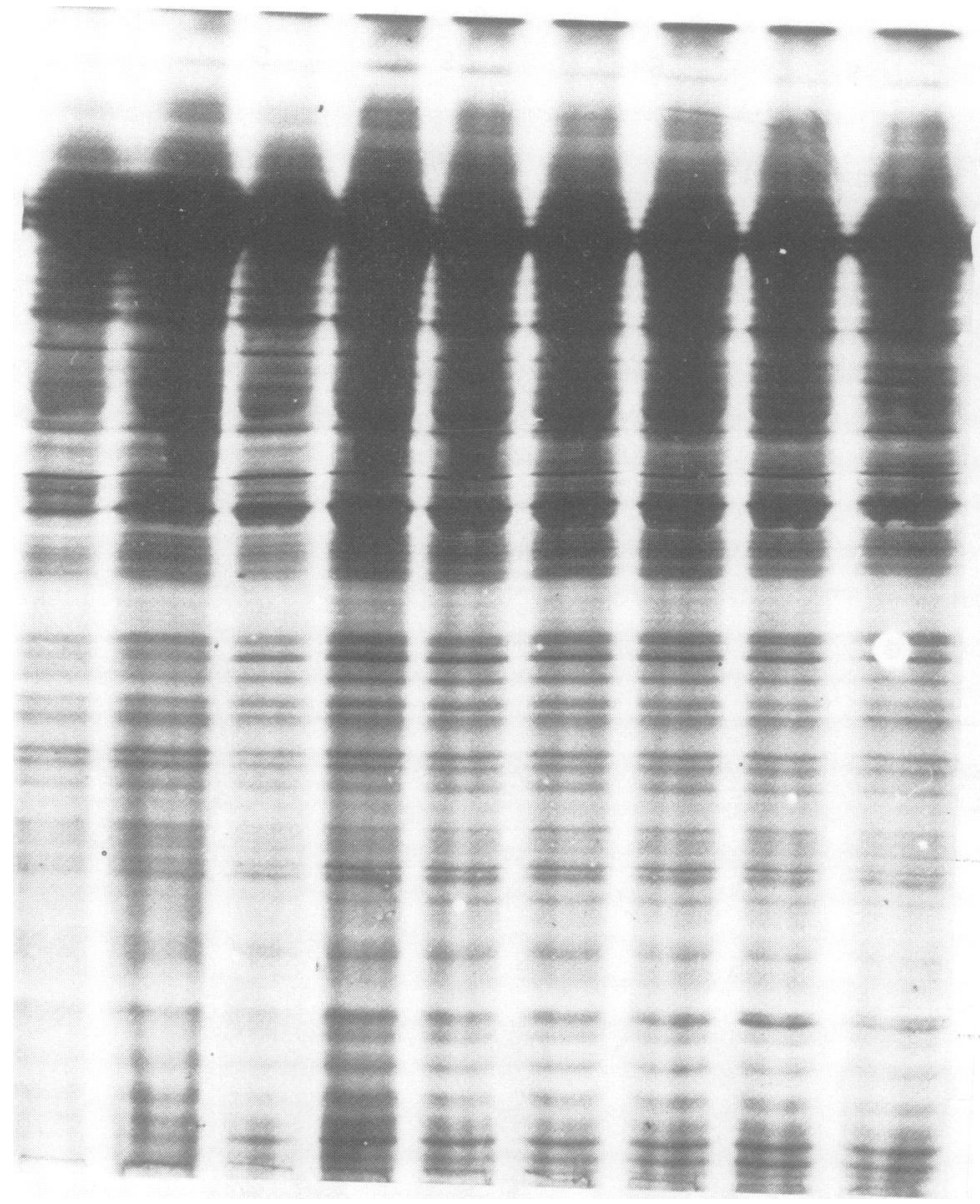

Fig (a) IEF on thin-layer polyacrylamide gels ( $p H$ range 3.5-10) followed by silver stain of diluted serum $(S)$ and unconcentrated CSF $(C)$. Multiple sclerosis patients (cases no 1 to 11) received $100.000 \mathrm{U}$ (cases no 1 to 6) or 640.000 U (cases no 7 to 11) of beta-interferon. For each multiple sclerosis individual, paired $\operatorname{serum}(S)$ and $\operatorname{CSF}(C)$ were run in parallel, after the application (open arrow) of 2 microgr. of $\mathrm{IgG}$ to the cathodic side (-) of the gel. The small black arrows underline the oligoclonal pattern of CSF IgG, which is clearly different from one patient to another. (b) IEF and silver stain of unconcentrated CSF obtained from the same individual (case No 2). The successive samples were collected during a six month period as described in the Material and Methods section (3rd week sample is lacking). Note the striking stability of the oligoclonal pattern.

(b)

a quantitative point of view, no significant change was observed during the survey, considering either the all patients group (table) or the two treatment subgroups separately (data not shown). The moderate increase in CSF IgG levels was due only to case No 7 with a $392 \%$ increase from week 1 to week 8 .
Otherwise, there was no modification in the clinical course of the disease in the 11 patients.

\section{Discussion}

These results were obtained with IEF of unconMean (SD) protein levels in serum and CSF for the all patients group during the six-month period of survey

\begin{tabular}{|c|c|c|c|c|c|c|c|c|c|c|}
\hline & $l$ & 2 & 3 & 4 & Week & Number & 7 & 8 & 12 & 24 \\
\hline $\begin{array}{l}\text { Serum } \\
\text { Albumin* } \\
\text { IgG* } \\
\text { CSF }\end{array}$ & $\begin{array}{l}38 \cdot 5(6 \cdot 2) \\
11 \cdot 1(1 \cdot 8)\end{array}$ & $\begin{array}{l}38 \cdot 3(4 \cdot 9) \\
11 \cdot 7(2 \cdot 8)\end{array}$ & $\begin{array}{l}38 \cdot 3(6 \cdot 1) \\
11 \cdot 0(2 \cdot 8)\end{array}$ & $\begin{array}{l}39 \cdot 2(5 \cdot 6) \\
11.4(2 \cdot 5)\end{array}$ & $\begin{array}{l}40 \cdot 3(5 \cdot 7) \\
11 \cdot 2(2 \cdot 0)\end{array}$ & $\begin{array}{l}36 \cdot 5(3 \cdot 5) \\
10.8(2 \cdot 6)\end{array}$ & $\begin{array}{l}38 \cdot 2(4 \cdot 1) \\
11 \cdot 4(2 \cdot 7)\end{array}$ & $\begin{array}{l}39 \cdot 2(4 \cdot 6) \\
11 \cdot 5(2 \cdot 2)\end{array}$ & $\begin{array}{l}38 \cdot 6(5 \cdot 5) \\
11 \cdot 0(2 \cdot 3)\end{array}$ & $\begin{array}{l}35 \cdot 0(3 \cdot 3) \\
10 \cdot 3(2 \cdot 5)\end{array}$ \\
\hline $\begin{array}{l}\text { Albumin } \ddagger \\
\text { IgG } \ddagger \\
\text { IgG/TP† } \\
\text { g/l. } \ddagger \mathrm{mg} / \mathrm{l} .\end{array}$ & $\begin{array}{c}345(174) \\
60 \cdot 5(22 \cdot 2) \\
11 \cdot 2(3 \cdot 6) \\
\end{array}$ & $\begin{array}{c}261(133) \\
60 \cdot 5(29 \cdot 7) \\
12 \cdot 8(5 \cdot 7)\end{array}$ & $\begin{array}{l}272(93) \\
63 \cdot 8(38 \cdot 5) \\
11 \cdot 9(4 \cdot 3)\end{array}$ & $\begin{array}{c}301(118) \\
60 \cdot 9 \cdot(18.8) \\
12 \cdot 0(3 \cdot 9)\end{array}$ & $\begin{array}{c}342(191) \\
65 \cdot 5(28 \cdot 3) \\
11 \cdot 8(3 \cdot 8)\end{array}$ & $\begin{array}{l}345(179) \\
65 \cdot 8(32 \cdot 1) \\
11.6(3.9)\end{array}$ & $\begin{array}{l}353(146) \\
78 \cdot 1(64 \cdot 7) \\
12.6(5 \cdot 6)\end{array}$ & $\begin{array}{c}365(183) \\
91.0(89 \cdot 2) \\
13 \cdot 8(6 \cdot 2)\end{array}$ & $\begin{array}{l}406(204) \\
90.3(57.4) \\
13.9(7.7)\end{array}$ & $\begin{array}{l}255(84) \\
78.8(59 \cdot 9) \\
15.5(8 \cdot 2)\end{array}$ \\
\hline \multicolumn{11}{|c|}{$\begin{array}{l}* \mathrm{~g} / \mathrm{l} . \neq \mathrm{mg} / \mathrm{l} . \\
+\mathrm{IgG} \text { to total proteins ratio }(\%)\end{array}$} \\
\hline
\end{tabular}


centrated CSF, a matter of importance as preliminary concentration of CSF is known possibly to result in artefactual patterns. ${ }^{8}$ The IgG specificity of the bands was inferred from previous work. ${ }^{14}$

The stability in the band pattern of CSF IgG we observed was not surprising. Indeed, the half-life of beta IFN, administrated in the cerebrospinal space is about 1 hour $^{15}$ and each sample was collected one week following each injection. Otherwise, this clonal stability has been documented using concentrated CSF by electrophoresis ${ }^{41116}$ and by IEF. $91016-18$ In fact, some variation in the oligoclonal pattern has been noted. ${ }^{10}$ Intensity of bands may vary. ${ }^{411}$ Individual bands may appear or disappear ${ }^{6}$ with a tendency towards a modest increase in band number with increasing duration of the disease. ${ }^{19}$ Moreover, the oligoclonal pattern may be lacking at the initial presentation of the disease and develop $\operatorname{later}^{20}$ or even never appear in necropsy-proven cases. ${ }^{21}$ However, once established, the overall pattern of oligoclonal CSF IgG does not change during the course of the disease in any individual patient. If changes occur, they are confined to individual bands. This stability is not consistently altered by treatment, either corticosteroids, ${ }^{111622}$ combination of antilymphocyte globulin, azathioprine and prednisone, ${ }^{6}$ or natural alpha-IFN. ${ }^{23}{ }^{24}$ In our experience, the band pattern of CSF IgG was remarkably stable within any individual over a six month period with intrathecal administration of natural beta-IFN.

Another striking finding of this study was the difference of the band pattern from one individual to another. This has been documented previously on concentrated CSF by electrophoresis ${ }^{11}$ and IEF. 111719

In summary, each patient had a unique band pattern of CSF IgG which did not change throughout a six month period with administration of natural betaIFN. This allowed the identification of each individual on the basis of the IEF separation of its CSF IgG, representing indeed a true "fingerprint". Although the exact mechanisms of the production of oligoclonal IgG in the CSF of multiple sclerosis patients is still unclear, it is important to stress that these patterns appeared absolutely fixed during the period of survey of our cases. Therefore, a modification of this oligloclonal pattern could be of significance with regard to the course of multiple sclerosis in individual patients. In addition, the consistency of this pattern could support the theory that oligoclonal CSF IgG have a definite, although yet unknown, antigenic target in multiple sclerosis.

We are indebted to Dr Marion Bernardet, UPSA Laboratories for the provision of natural beta-IFN, Miss Dominique Morel for excellent technical assis- tance, Mrs S Droguet and M Verger for secretarial work.

This study was supported in part by the Association pour la Recherche sur la Sclérose En Plaques (ARSEP).

\section{References}

${ }^{1}$ Lowenthal A. Agar Gel Electrophoresis in Neurology. Amsterdam: Elsevier. 1964.

${ }^{2}$ Laterre EC. Les protéines du Liquide Céphalo-rachidien à l'état Normal et Pathologique. Bruxelles. Editions Arscia SA. 1964.

${ }^{3}$ Link H. Immunoglobulin $G$ and low molecular weight proteins in human cerebrospinal fluid: chemical and immunological characterisation with special reference to multiple sclerosis. Acta Neurol Scand 1967;43 (suppl 28):1-136.

${ }^{4}$ Olsson JE, Link H. Immunoglobulin abnormalities in Multiple Sclerosis. Relation to clinical parameters: exacerbations and remissions. Arch Neurol 1973;28:392-9.

${ }^{5}$ Vandvik B. Oligoclonal IgG and free light chains in the cerebrospinal fluid of patients with multiple sclerosis and infectious diseases of the central nervous system. Scand J Immunol 1977;6:913-22.

${ }^{6}$ Thompson EJ, Kaufmann P, Rudge P. Sequential changes in oligoclonal patterns during the course of multiple sclerosis. $J$ Neurol Neurosurg Psychiatry 1983;46:547-50.

${ }^{7}$ Delmotte P. Gel isoelectric focusing of cerebrospinal fluid proteins: a potential diagnostic tool. Z Clin Chem Klin Biochem 1971;9:334-6.

${ }^{8}$ Thompson EJ. Laboratory diagnosis of Multiple Sclerosis: immunological and biochemical aspects. Br Med Bull 1977;33:28-33.

${ }^{9}$ Delmotte P, Gonsette G. Biochemical findings in multiple sclerosis: IV. Isoelectric focusing of the CSF gamma globulins in multiple sclerosis and other neurological diseases. J Neurol 1977;215:27-37.

${ }^{10}$ Siden A, Kjellin KG. CSF protein examinations with thin-layer isoelectric focusing in multiple sclerosis. $J$ Neurol Sci 1978;39:131-46.

${ }^{11}$ Olsson JE, Nilsson K. Gammaglobulins of CSF and serum in multiple sclerosis: isoelectric focusing on polyacrylamide gel and agar gel electrophoresis. Neurology 1979;29:1383-91.

${ }^{12}$ MacAlpine D, Lumsden CE, Acheson ED. Multiple Sclerosis. A Reappraisal. Edinburgh: Churchill Livingstone. 1972.

${ }^{13}$ Confavreux C, Aimard G, Devic M. Course and prognosis of multiple sclerosis assessed by the computerized data processing of 349 patients. Brain 1980;103: 281-300.

${ }^{14}$ Confavreux C, Gianazza E, Chazot G, Lasne Y, Arnaud P. Silver stain after isoelectric focusing of unconcentrated cerebrospinal fluid: visualization of total protein and direct immunofixation of immunoglobulin $\mathrm{G}$. Electrophoresis 1982;3:206-10.

${ }^{15}$ Ho M, Nash C, Morgan CW, Armstrong JA, Carroll RG, Postic B. Interferon administered in the cerebrospinal 
space and its effect on rabies in rabbits. Infect Immun 1974;9:286-93.

${ }^{16}$ Hershey LA, Trotter JL. The use and abuse of the cerebrospinal fluid IgG profile in the adult: a practical evaluation. Ann Neurol 1980;8:426-34.

${ }^{17}$ Livrea $P$, Trojano $M$, Simone IL, Zimatore GB, Lamontanara $G$, Leante $R$. Intrathecal IgG synthesis in multiple sclerosis. Comparison between isoelectric focusing and quantitative estimation of cerebrospinal fluid IgG. J Neurol 1981;224:159-69.

${ }^{18}$ Walsh MJ, Tourtelotte WW. IgG, IgM and IgA temporal clonal stability in Multiple Sclerosis. Neurology 1983;33 (suppl 2):123 (abstract).

${ }^{19}$ Mattson DH, Roos RP, Arnason BGW. Comparison of agar gel electrophoresis and isoelectric focusing in Multiple Sclerosis and Subacute Sclerosing Panencephalitis. Ann Neurol 1981;9:34-41.

${ }^{20}$ Sandberg-Wollheim M. Optic neuritis: studies on the cerebrospinal fluid in relation to clinical course in 61 patients. Acta Neurol Scand 1975;52:167-78.

${ }^{21}$ Farrell MA, Kaufmann JCE, Gilbert JJ, Noseworthy JH, Armstrong HA, Ebers GC. Oligoclonal bands in multiple sclerosis: clinical-pathologic correlation. Neurology 1985;35:212-8.

${ }^{22}$ Baumhefner RW, Staugaitis SM, Tourtelotte WW, Shapshak P, Chuang E. Modest reduction of oligoclonal banding in multiple sclerosis with adrenocorticotropic hormone and corticosteroids. Ann Neurol 1984;16:142 (abstract).

${ }^{23}$ Panitch HS, Francis GS, Hooper CJ, Fukushima PI, Bleumers EB, Johnson KP. Serial immunologic studies in Multiple Sclerosis (MS) patients treated with natural alpha Interferon (IFN). Neurology. 1984;34 (suppl 1): 111 (abstract).

${ }^{24}$ Rice GPA, Talbot P, Woelfel EM, et al. Immunological observations in patients with multiple sclerosis treated with human alpha Interferon. Neurology 1984;34 (suppl 1):112 (abstract). 